\title{
Reading Between the Lines: Ben Morea on Anarchy, Radicalism, and Revolution
}

Breanne Fahs

Having incited some of the most politically significant radical actions of the 1960s, Ben Morea-American activist, leader and co-founder of Up Against the Wall, Motherfucker, anarchist, artist, and cultural revolutionary-went underground abruptly for nearly 40 years. With most of his stories largely untold, he has reemerged as a voice of late 1960s activism to bridge the gap between the last four decades of struggle. What lessons can we learn from the radical paths already forged by Morea and his contemporaries?

As a writer for the radical newspaper Black Mask, leader of radical militants that stormed the Pentagon during an anti-war protest (1967), occupier of buildings at Columbia University (1968), participator in the cutting of fences and handing out of tents at Woodstock (1969), and vocal cultural critic of nearly all oppressive institutions in late 1960s U.S. culture, Morea earned a reputation as an elusive cultural radical. Morea believed that radicals could only enact social change if they stayed committed to multiple avenues of social change-in particular, cultural, political, and artistic rebellions. Disinterested in moderate or incremental social change, Morea redefined the "kinship" structures of radical late-1960s activist groups by reinventing a new family intent on radical upheaval, rupture, and dissent. Kicked out of the Situationists for criticizing their tactics and ideologies, forming an intimate friendship with Valerie Solanas (author of SCUM Manifesto and would-be assassin of Andy Warhol), being asked to run for Vice President with Eldridge Cleaver, and organizing the Motherfuckers to dump uncollected trash from the Lower East Side into the Lincoln Center fountain during a February 1968 gala event ("Garbage for garbage"1) represent only a few of his colorful and significant political actions.

As a leader and ally to current radical movements everywhere, Morea re-emerges in this interview piece during a time of cultural crisis to consider the meaning of anarchy, radicalism, and resistance in the age of al-Qaeda, Sarah Palin, Egyptian political unrest, and the Internet. As a nucleus of 1960s counterculture, Morea reflects on his involvement in politics, art, and culture, including his connection with Valerie Solanas, his decision to disappear after believing he would be assassinated at the ' 68 Chicago convention, and his thoughts about anarchy, sexuality, politics, spirituality, creativity, and self-care as a radical.

Born in 1941, Ben Morea founded the Dada-influenced art group, Black Mask, in 1966 with fellow activists and artists (including Dan Georgakas and Ron Hahne) as a way to integrate revolutionary art and cultural criticism into the broader cultural consciousness of late 1960s New York City culture. Called "the 
first self-styled anarchist"2 and a self-described "self-educated ghetto kid and painter,"3 Morea wanted to unite the radical ideas of Dadaism and Surrealism with anarchy and revolution. Relocating from Maryland and Virginia to Manhattan at age ten, Morea used his experiences with drug addiction and prison as a teenager to reinvent himself as an artist with social awareness. ${ }^{4}$

In 1968, Black Mask evolved into Up Against the Wall, Motherfucker 5; as Morea said, "There was no decision to start a new group, no blueprint, it was just an evolutionary thing where one died away and the next thing came to be. It's hard to say exactly at which point one ended and the next began." 6 Named for an Amiri Baraka poem 7 , the group did not receive consistent press coverage because of their "obscene" name. Abbie Hoffman, founder of the Yippies and one of the Chicago Eight, called the group, "the middle-class nightmare... an anti-media phenomenon simply because their name could not be printed." 8 The group included Osha Neumann (painter, sculptor, and political activist), Ron Hahne (artist), John Sundstrom (artist), and Alan Hoffman (former editor of anarchist magazine, Good Soup).

The Motherfuckers considered themselves an "affinity group" — a term coined by Morea to mean a non-hierarchical, decentralized group of activists who prioritize consensus, direct action, and common ideologies 9 —and supported New York City's counterculture by setting up "crash pads," serving free food, starting a free store (where goods are given away freely after being donated freely), and connecting runaways and street people with doctors and lawyers, a mimeograph, and access to fake IDs. ${ }^{10}$ Dubbed a "street gang with analysis,"11 the group combined confrontational theater and tactics used by Black Mask with more aggressive tactics for confronting police and other authorities. The Motherfuckers staged an "assassination" of poet Kenneth Koch where they used blanks instead of bullets, shut down the Museum of Modern Art in New York City, protested Wall Street's bankrolling of war, resisted any State control over protest actions, and became the only non-student chapter of the Students for a Democratic Society (and notoriously fought with vanguard Maoists at SDS conferences). ${ }^{12}$ Resisting appropriation from both the Right and the Left, Ben Morea and the Motherfuckers supported a complete cultural revolution and influenced radical groups everywhere: The Weathermen, the Yippies, and "hippy" communal movements across the nation. As Black Mask declared, "Yes, Revolution. A revolution whose scope is as wide as the cosmos (from telescope to microscope), whose power is as strong as the millions who inhabit the thirdworld or the rockets which pierce the outer-world. A revolution which will destroy the exploitative traditions of the west including those noxious philosophies, liberalism and humanism, in whose name the world has been laid open to plunder ... Now we must decide what we will do."13 
The following interview occurred on March 10, 2011 and represents a condensed version of a longer transcript from a two-hour conversation. This interview is one of only a few interviews he has granted since he re-emerged assuming his actual identity. As our interview initially addressed his relationship to Valerie Solanas, the piece begins with his memories of Solanas and then transitions into broader reflections on anarchy, politics, and resistance. I have divided the interview into three primary sections: first, his relationship with Valerie Solanas and his reflections on radical feminism; second, his ideas about radicalism and its meaning both historically and in contemporary society; and third, his reflections on anarchy, co-optation, and resistance.

\section{Section 1: Valerie Solanas and Radical Feminism}

As the embodiment of women's rage in the late 1960s, Valerie Solanas became a source of controversy, contention, and identification within and outside of the feminist movement. Having written one of the most vitriolic (and potentially satirical) texts of her day, Valerie Solanas's SCUM Manifesto (1967) ${ }^{14}$ argued for a complete upheaval in all social institutions that prioritized men and patriarchy (e.g., art, culture, politics, science, marriage, law, education, and so on) along with the systematic elimination of all men. After shooting Andy Warhol on June 3, 1968, Solanas faced ostracism and rejection from all but the most radical segments of the Left. Morea reflects here on his relationship with Solanas, her influential ideas about the role of women in society, and the (mis)appropriations of her life and work.

FAHS: I'm interested to hear how you met Valerie [Solanas].

MOREA: I published an anarchist, artistic, cultural paper called Black Mask and I used to on occasion sell it on the street for a nickel. Monetary-gain wasn't the purpose. The nickel was just that if you hand it out free people take it no matter what. So, I thought for a nickel they would go out of their way to get it and look at it. So I used to charge a nickel. One day I was selling the paper in the village and Valerie, who I didn't know at the time, came up to me and said she would like to get a copy, but she didn't have a nickel. I told her, 'You don't really need a nickel. Since you want a copy, you can have it. I only charge a nickel to make sure somebody wants it." She said, "No, no. Wait here," and she went into a bookstore and stole a copy of her own book, SCUM Manifesto, brought the book back to me, and said, "Here, I'll trade you." She just went and stole it from some bookstore. That's how I met her. I immediately was attached to her, her effort. It impressed me. I can remember that over time we just got closer and closer, more friendly, and then for a period of time she used to stay with me. I had a loft then and I was also an artist. I cannot remember how she told me, or I knew, or I sensed that she was transient and didn't have a permanent place. I made my home available to her. She used to come and stay with me on occasion, just 
overnight, maybe several nights in a row, and then I wouldn't see her for a few nights.

FAHS: So what do you remember about her? What do you remember about the ways you two overlapped?

MOREA: I don't know. She never used the word anarchist, but she came really close to having the same ideas I had. We shared a lot. I had a strong animosity towards Andy [Warhol] and that whole bunch and obviously she had some, which we agreed upon. We were very strongly opposed to Andy. She felt he had stolen her play. You know I loved her. She was a very beautiful person, but she was a little unbalanced, which never bothered me and still doesn't bother me. I had such strong feelings, good feelings for her. But I don't know if Andy really did steal her play or just held it longer then she had wanted. You know, I really don't know how that evolved. In her mind, she was fixated with the fact that he had stolen it.

FAHS: Tell me more about the relationship that the two of you had.

MOREA: She was fairly mild mannered compared to what people would assume by her actions. It was never obvious that she would go to that extreme. She was not an aggressive person. She was very nice and she was very sweet around me all the time. In the movie, they show that we had some sexual liaison which was completely untrue. We were just really close friends, a platonic relationship rather than a physical relationship. One evening I said to her, "You know Valerie, I was wondering, your main focus is killing men and here I am, a man. What does that mean?" She looked at me and said she had never thought of that in those terms. She thought for a minute and said, "Well I promise you, you'll be the last man we kill." In other words, she didn't take herself overly serious. She was easy to get along with, and a lot of the conversation was about what I've been doing, things I was involved with, and thoughts that I had or thoughts that she had about art in general and politics how it affected art and vice versa, how art affected politics. At one point, I was involved in occupying one of the building at Columbia University, and she came down to see me. She said, "Hey, Ben, what would happen if I shot somebody?" I said, "Well, it depends on two things: Who do you shoot, and if they die or not." And a week later she shot him.

FAHS: What kind of state was she in when she talked to you about that?

MOREA: She didn't really seem that different than when I normally would see her. She wasn't animated or more troubled then. I don't mean this negatively, but she always had a certain craziness about her. And her question just seemed like a matter-of-fact question, and it was a week later that she shot him. Valerie has been somewhat vilified and I would actually lead that program to Andy himself. I would vilify him, not her. But, you know, I'm not the norm. To me, she was a 
much better person, a more honest person than Andy was. Andy was the most manipulative, dishonest person and he used art as a commodity. Aesthetically and ideologically, I would lean much more toward her than towards him. I would vilify him for trying to destroy the creative act and make it a money act. I mean, he really stands out as a negative factor to me and she does not. While we're on the subject, in the movie it shows her stealing the gun from me and that was not true. I mean, I had guns and my family [Up Against the Wall, Motherfucker] had guns at the time, but she would never steal from me and I don't know where she got the gun. I left there soon after and I never saw her again. I became more transient myself. Up Against the Wall had four or five crash pads so to speak, and I would rotate between them.

FAHS: In terms of your relationship, so you decided not to have any kind of sexual relationship. Was Valerie having any kind of sexual relationships at the time with anyone else?

MOREA: I assumed that she was either asexual, bisexual, but she had lesbian tendencies and I couldn't tell and it didn't matter to me if she mainly thought of herself as lesbian or if she was bisexual. I mean, I could tell that her sexuality was less defined by the norm. We didn't have that kind of relationship, that kind of appeal towards each other. We had a bond. A kind of friendship bond. She was my buddy. We particularly bonded over our dislike of Andy. She disliked his manipulation of people. She was opposed to that relationship between men and women, that sense of manipulation, and it became aesthetic as well as political. She was calm and mellow with me, but you've got to remember, I was a pretty volatile person in those days. Maybe if she was around a liberal, she would have come across as more threatening and strong, but around me, it didn't come off that way at all. She was my friend, my equal. She was her own person. You could just tell that she was not what we in the 60 s used to call "straight." I mean, she was just not a straight person, a person who was wrought in this materialistic world. She had an edge to her. It wasn't like she was overtly crazy. She was crazy in the sense that we all were on my end of the spectrum. We were all opposed to this materialistic, dominant, oppressive world that the straights loved. We made it clear by our actions, our thoughts, our appearance. We tried to make it clear that we were not part of the straight world and you could tell she was not. Had she been a straight person, we probably wouldn't have had the relationship that we had. But I was not really open or friendly to straight people at all. I had no interest in it, in that world or the people from that world.

FAHS: What do you make of the fact that she ended up in mental hospitals?

MOREA: The alternative was much worse-ending up in prison. So, I'm glad in a way that they charged her mentally unfit so that her punishment for the crime_-shooting somebody — was a mental hospital rather than a prison. I don't 
think she did it purposefully. They sensed that she was wounded in the real world and classified her as a mental case. The alternative would have been prison and that wouldn't have been any better.

FAHS: Tell me about the relationship you sensed she had to her writings. What was she working on when the two of you knew each other?

MOREA: Well, she was one hundred percent artist. One hundred percent writer. It was always part of the conversation and part of her life, writing her thoughts, her desire to communicate ideas. It came up all the time. It was just part of our conversation. As far as specific works that she had written, the only thing that ever came up was the play and that had already been written.

FAHS: But you thought that she was very connected to her ideas and to talking through ideas with people?

MOREA: Right. Absolutely.

FAHS: Who did she imagine as her audience, do you think?

MOREA: I don't know. That never came up. At that time, we had an audience. We had a world opening up that was equally opposed to the straight environment that we were in. We had this whole world that we inhabited on the Lower East Side in the village. After she shot Andy, I went up town and handed out a statement form supporting her. I mimeographed it and handed it out.

FAHS: What did you think of the movie?

MOREA: I liked it. I thought that it was such a true portrayal of her and that it didn't bother me that they showed us having a sexual liaison because they couldn't find me. They tried to find me. See, I was out of communication for at least forty years. You couldn't find me if you wanted to. This conversation would not have happened if I hadn't reemerged like three or four years ago. In many ways, the film's portrayal of our sexual liaison didn't bother me because they had no other way to show how close we really were other than that. People couldn't understand it in just platonic terms. They couldn't understand closeness without sex.

FAHS: How do you think someone would do justice to Valerie's story? ${ }^{\text {15 }}$

MOREA: The best I'd ever hope is that she was given respect as a woman of thought and a woman of letters rather than as a maniacal killer. I would hope that people would see the creative, the important side of her, and respect her for that. Of course she was an artist. André Breton, once said something like, "To go out and randomly kill somebody is a revolutionary act, a surrealistic act." In other words, it's not a homicidal act, but even if it was a homicidal act, she was justified as far as I'm concerned. 
FAHS: I guess I feel conflict sometimes about what it means to tell a story about someone who probably would have been pretty upset about someone trying to do that.

MOREA: I don't know. I don't think she would have been upset if the story illuminated her true nature, her creativity. She had a purpose. She was driven by a purpose. She saw a vacuum that she felt that she could delineate. I think that she would have been in some ways grateful to have that exposure. I think that if somebody wrote a negative piece about her and made the high point of her life shooting Andy, she would have been upset, rightfully, because that wasn't the highpoint. That was just a footnote. She existed independent of the act of shooting Andy. She existed as a writer. Shooting Andy was just an aside, irrelevantly aside as far as I'm concerned. But, those who feel that Andy was important, they would feel differently.

FAHS: So what are your thoughts on the tenuous relationship between Valerie and feminism?

MOREA: I would never want to put words in her mouth, but my sense is that she had a real distaste for liberals of all stripes including feminist liberals. She had a disdain for liberal feminists because she saw herself as a radical, just as I had a disdain for political liberals because I consider myself a radical. She spoke of her disgust, how stupid they were, or how shallow they were, or how one dimensional they were, but she never came across as a really angry person. She came across as a person angered by stupidity and angered by the situation that existed but not as an angry person. I was much more like that than she was. She had a lot to contribute to the feminist political world and had a lot to offer and should be taken seriously. I had a lot to offer in my world, in my arena, the more political, artistic, cultural world, in general. Radical feminists who reject Valerie aren't radical feminists. It's a game. They're liberal. They were afraid to go that last mile. Radicals are ready to go over the edge. Liberals just go so far. She threatened them because she went all the way. She played out her conviction rather than just riding it. I played out my conviction rather than just riding it. That's the difference between radicals and liberals.

\section{Section 2: Radicalism}

As an advocate of radicalism and a champion of all social movements that seek freedom from state intervention, Morea spent much of the late 1960s staging protests and events that drew from lessons learned from other social movements (particularly radical art movements throughout the world). Here Morea reflects on the historical and contemporary role of radicalism in shaping political consciousness and as having the potential for revolution. From the seemingly personal events of our lives (Morea never married in a state-sponsored sense but 
Fahs

has maintained a relationship with his companion for over 40 years) to the blatantly political spaces we inhabit, Morea argues that radicals must live their ideologies. By framing lessons learned from all revolutions-from the Russian revolution to current upheavals in Egypt-Morea conceptualizes the role of radicalism in making, unmaking, and remaking the world.

FAHS: Can you tell me a little more about what you think radicalism does or can do or has done?

MOREA: It's moved the world continually. You could go back to the 1800 s or you could go all the way back, but I mean, what we call the American Revolution came about through radicals. The French Revolution, the Russian Revolution. Regardless of whether they were betrayed at some point, they were beneficial movements to humanity. It doesn't matter that it went corrupt and we ended up with communism and Stalinism. It's just like what's happening in the Middle East. You can see it right now. The Egyptian, Tunisian, Libyan uprisings are a benefit to mankind, regardless of what's going to happen eventually. Some corruption, authoritarianism might creep in, but it doesn't matter. It's a breath of fresh air and that's what radicals believe. They're looking for that breath of fresh air. They don't say to themselves, "Oh, well, we ended up with Stalin, so how good could the Russian revolution be?” We look at it like the Russian Revolution was a boom to mankind. It pushed man to the next step and the American Revolution did the same. We don't look at the American Revolution and say, "Everything that is stood for is being undermined and corrupted now." We don't look at it like that. We look at the fact that it was a boom to mankind. That's the difference. Radicals don't fear events. They feel that they propel events. Liberals are always afraid.

FAHS: What you're saying is that the context and the time and place matters to a point but not as much as the bigger story, right? The bigger story of upheaval and rebellion?

MOREA: Right. Rebellion is a creative act. It's a propelling of man that moves forward. After the American Revolution, man had a chance to be freer, or after the French revolution, man had a chance to be freer than he could be before it. After the Russian revolution, man had a chance to be freer than he could before it. It doesn't matter at some point that the anti-revolution sets in. It doesn't diminish that moment, that breath of fresh air that the rebellion represented. Like, for instance, Egypt today. ${ }^{16}$ Even if Egypt slid into a military dictatorship at some point, we would never say that the Egyptian revolution was in vain. It cannot be in vain. It is. It's a beautiful act. It's a work of art. So, even if it slides into a negative place, it doesn't diminish the act or the aesthetic or the art of it. Can you see? 
FAHS: Yes. One of my biggest frustrations with liberalism in general is that it's so preoccupied with only the outcome and not with the process.

MOREA: Absolutely.

FAHS: I'm teaching a class on radicalism, and it's hard to shift the discourse so that it's not always about where we land.

MOREA: It's never about end. It's always a process. That's what revolution is: process. It's not end. It's not regime change. It's about process. Expansion of the human condition, moving forward. And without revolution, you have stagnation. Say like Cuba for instance. That was fantastic that those guys in the mountains overthrew Batista. It doesn't matter that Fidel became a dictator. That doesn't diminish what they did in the mountains, and that they overthrew Batista, and that they overthrew the American dream of a gambling paradise. That's what Cuba represented to America - the next exploitative paradise for the wealthy and gambling classes to go, with no concern for the people of Cuba that were oppressed. So, it doesn't matter to us if Fidel became a dictator. It doesn't diminish the act itself. The Cuban revolution is still a beautiful thing. Does that make any sense?

FAHS: Yeah absolutely. Like you and Valerie. You were in different orbits, but those orbits are still propelled by the same goal.

MOREA: Exactly. That's exactly it.

FAHS: What you're talking about also makes me wonder: Where do women factor into this? What do we do with sexuality? It's helpful to hear your vision of this bigger picture, that we don't necessarily have to align in these very precise ways.

MOREA: Absolutely that's true. That's the key for radicals. Not trying to fit an agenda. That's why I got kicked out of the Situationists because of that exactly. They wanted to make sure that it was exactly as they wanted or exactly as they thought it should be, exactly their ideology or whatever. I was just into the act itself.

FAHS: What are some of the moments that you can recall where radicalism has triumphed, especially in the last period where you were off the grid?

MOREA: Well, you're in your early 30s so you wouldn't know what the world was like in the 50s, but let me tell you this, the world we inhabit has no similarity whatsoever to the 50s. The 60s broke that whole structure down, destroyed it. Even though it didn't bring about a regime change, it brought about tremendous change: culturally, artistically, philosophically, politically. The 60 s was extremely successful in some sense, like for instance just a mundane thing like stopping at a 
Fahs

convenience store. In the 50s, when you stopped at a convenience store, all you could get was white bread and Coca Cola. But today, look at all the healthy items that you could get. That's part of the whole concept that the 60s brought up, that what you eat is part of your life. Just the whole expansion of the Internet, the whole "Wikileaks" event— that couldn't have happened without the 60s. The 60 s really accomplished a lot. There are people who thought it was a failure, but it was not a failure. It's just that they're a failure because they can't see how to go forward and what to do next.

FAHS: What would radical feminism look like to you?

MOREA: I don't know. I'm obviously not a woman. I can't see it from that perspective. I believe a woman has to decide. I think Valerie was on to something. I would assume her voice had some resonance and validity that I don't have. I can't speak for the "feminist revolution." She tried to add something to it. It wasn't the whole picture, obviously. You know she missed part of it, I'm sure.

FAHS: Do you think there could be such thing as a radical sexuality?

MOREA: Absolutely. In my opinion, sexuality is creation itself, a creative act. The universe was created through movement and convergence and sexuality is just a mundane version of that. It's a very high spiritual thing and it's been used as a form of oppression, but it's a beautiful thing. I think that's part of the error in feminism is that they may throw away the baby with the bath water. In other words, it's not sexuality that's wrong, it's the use of sexuality as a tool of oppression that's wrong, but sexuality itself is beautiful. It's a gift, much misused.

FAHS: I'm thinking also of other radical feminist writings and critiques of love and marriage. What would you say about reconciling those with radicalism?

MOREA: I'm limited to my one-sided view. I can't see it from both sides, from the woman's perspective, but I can tell you my own. I've been with the same woman for 41 years and we never have been married. I always thought that the paper that says you're married is not only unnecessary but can be a hindrance. The relationship has to be pure love. It can't be paper.

FAHS: Has that worked for you?

MOREA: Yeah. It's worked for me.

\section{Section 3: Anarchy, Co-optation, and Resistance}

Reflecting on his own life-including radical actions with his affinity groups in New York and his disappearance in 1968-Morea considers the role of anarchy in shaping the forces of social change. By considering the importance of avoiding or resisting co-optation, Morea argues that radicals must always remain one step ahead of the state and its accomplices. In this final section, Morea considers 
a host of subjects often ignored by radicals-particularly self-care, creativity, and spirituality-in framing his vision of a more radical future.

FAHS: Tell me what you think of the role of anarchy today and what vision you have for anarchists moving forward.

MOREA: It's in the ascendancy right now. If you just look around the world, it's everywhere. An anarchist does not see anarchy as the dominant political forces would like you to see it as, as some form of chaos. Anarchy to us is self-regulation, non-oppressive situations, room for people to grow and express themselves independent of ideology. It's everywhere, in Greece, Spain, Portugal, France, in the Middle East and North Africa - they're all anarchists, even if they don't use the word anarchy. A lot of those kids who propelled the upheaval in North Africa had anarchistic leanings. It wasn't ideological, either Islamic or socialist or communist, but rather, much closer to anarchist. They don't have an agenda. They don't have a "party." They have a desire to be free. They've gotten a lot of criticism for this, that they don't have a platform, but to us as anarchists, that's beautiful. They're just moving, trying to be free. Take the analogy of a room with no air. You want to get air, you want to bust a window. You don't want to think to yourself, "What do I do with a broken window?" You just want to break the window, get some air. That's how anarchists feel. In other words, we don't need to have a blueprint. Hopefully man will figure out what to do with his life as he goes forward, but we need the air, we need to breathe. And you're not going to breathe with Mubarak or Gadhafi blowing smoke. Or al-Qaeda. The only way that you're going to defeat al-Qaeda or Islamic extremism is self-regulatory extremism, people desiring to be free. If we don't help it or grasp it, it's going to slip. The Islamic movement will take advantage of it and recapture what the youth in the freedom-seeking people have accomplished. Fundamentalists are the problem. Fundamentalism is the problem. It doesn't matter if it's Islamic fundamentalism like al-Qaeda or American fundamentalism. Palin is as much a problem as Osama Bin Laden. Rush Limbaugh is as much a problem as Bin Laden, as far as I can see. The problem is fundamentalism. So here you have a movement that has shaken the nation to its core and it's not fundamentalists. We should be embracing it. Instead, we don't know what to do with it. We're confused. "Who really controls it?," they keep saying. The truth is, nobody controls it, and that's the beauty of it. But, somebody will end up controlling it. That always happens. So, we should be able to push it towards them, the freedom end of the spectrum.

FAHS: Radicalism movies the center and lurches it out of being stagnant or stuck.

MOREA: Right. Exactly. 
FAHS: I'm also interested to hear about your disappearance, how you've lived off the grid for 40 years, and why you left, why you came back.

MOREA: I can tell you a little about that. I don't want to be too specific. It started in ' 68 , ' 69 when a lot of radicals were being assassinated and killed by the government, like different Panthers. I was going to the Chicago protests in '68. ${ }^{17}$ I was on my way there and my girlfriend at the time had a blue Volkswagen that I often traveled with her in. On my way to Chicago, I was stopping different places, visited friends, and I kept getting calls about blue Volkswagens getting stopped around Chicago. The cops had my picture and they approached the car armed as if they were waiting for some provocation, weapons unsheathed. After the third call telling me the same thing, I didn't go to Chicago. I took off and never came back. And I went into the mountains on horseback for five years.

FAHS: Did you know how to survive doing that?

MOREA: In my childhood, I was a rural country kid. I was always around horses. I worked in stables and I slowly learned survival as a child. I became a survivalist. I could teach people about edible plants. When I disappeared, I slowly changed my identity and just stayed out, so to speak, until four years ago.

FAHS: And why did you decide to come back?

MOREA: That was somewhat serendipitous also. Some lady I knew that I hadn't seen since the 60s (and I don't know how she knew how to get a hold of me or where I was), she asked me if I would appear someplace, as myself and talk to people. I laughed and told her, "Absolutely not. Are you nuts?" I thought about it, though, and how we've reached that "dead end point" again (if not worse) like the 60s. I thought to myself, "What are you going to do now? Are you going to just ignore how bad things have gotten?" I called her back and said, if you keep it to a small audience-because I haven't spoken to anyone in 40 years about these types of things and I'm not used to it or comfortable with it—I'll try it. So, I went to New York at some event with radical people, 20 or so, and I felt a little comfortable with it even though I was also apprehensive. And it just kept growing and other people contacted me. I live out of New York State but I visit often.

FAHS: Are you worried about your safety now?

MOREA: Not as much obviously, but still, it's always there. It's not as prevalent as it was forty years ago. There's a lot of interest from radicals about how we did what we did. That's why I decided to reemerge. I have a lot of information. I knew a lot of people. Lots of stories haven't come out. We cut the fences at Woodstock. Nobody knew that until I reemerged and let people know that the fences didn't just fall down. I came back because I felt like I'm getting older and 
God forbid something happens to me, do I want to take all that information with me? I wanted to leave some of it, like, you know, Eldridge Cleaver asked me to run for Vice President. I laughed it off. I said, "Are you crazy? I'm an anarchist!" Our connection to the black struggle was so strong. In other words, I want to share things with people so that they can make up their own minds about how things should be done in the future.

FAHS: I know someone who says that no one's born a radical. Would you agree?

MOREA: It depends how you define radical. We're all born and we all have consciousness, so that consciousness is shaped partially by the environment, partially serendipitous when you run into certain things, and it may change you. There are so many myriad events that you can never give one cause. It's a combination of environment, your own mental capacities, what you see, how you take it. They all shape you and some people see it in a light that leads to radicalism.

FAHS: Radicalism is also tricky because it has so much energy around it that it can be overwhelming. Students tell me radicalism makes them feel disorganized. I think it's hard to reconcile day-to-day life with the energy of radicalism. How do you put those things together?

MOREA: Well you're absolutely right. It's difficult, and the way we did it in the 60 s cannot be done again. In the 60 s there was a whole cultural upheaval going on at the same time that we were part of. We were part of that whole countercultural upheaval. Now it's talked about like "The fish in the sea." That was our sea, so it's going to be a little different this time around and it's a little more difficult. Young people will find a way. I'm sure the Internet is going to play a big part in it. It already has. Each generation has defined the tools and the media and/or environment that they need to flourish. There is no blueprint, but people will still find their way.

Being a radical, being the kind of person $\mathrm{I}$ am, I had to find a way to make a living that I was comfortable with, so I got to selling antiques and collectibles, which I do now. Before that, I was a lumberjack, which is very independent and artistic. I was a rancher. I had livestock. You find ways that suit your personality and/or conviction. I could never be a banker. You find ways and obviously art is one of the ways. People gravitate to where they can survive. I don't take part in any of the social media use of the Internet. I don't do Facebook or Twitter or whatever. I don't do that. I use email and obviously I do my blog, which is very simple and small, so I'm not super preoccupied with the computer. In Egypt or Iran, the Internet wasn't successful yet, but it helped. It alerts people to how to proceed day-to-day, where to meet or where to converge. In a repressive society, it can really help, even though it has a potential for its own repression. There's always a duality to things. The act of revolution carries 
its own downfall with it. They coexist, just like life and death.

FAHS: Yeah, I struggle with that to because it seems like every time we get creative and come up with this new way of empowering people or fighting against repressive regimes or radically changing people's personal lives, it's so soon after that it gets appropriated again, and we have to just go back to work. It's so unbelievable.

MOREA: Cooptation is the game. You always have to stay one step ahead of cooptation. You've got to use things without being co-opted. That's a dance. I don't think you can tell anybody how to dance. You need to feel rhythm or you don't. Each person has to figure out a way to do this.

FAHS: So what you're saying is that people should try hard to sense when cooptation and oppression are coming and then shift their strategy first?

MOREA: I think so, yes. Cooptation not only can happen, but will happen. Be aware of it so that you're precluding it happening by what you do. I'll show you an example. In the 60 s, people who thought like I did sensed how easy cooptation was. We would do certain things to minimize cooptation. I would never allow myself to be photographed or become a "personality." That might seem like a small thing, but Abbie Hoffman and those guys did the opposite. They wanted to be shown. Whenever they saw a camera, they would run to it. They were co-opted so fast. You sense things. Like our name-Up Against the Wall, Motherfucker-was one of those. We didn't choose that as a name, but it actually helped us because you couldn't write about us in a lot of the regular media. That helped us from being co-opted. I think everybody should be aware that cooptation is working. You have to be aware of it and guard against it all the time. The desire to be a star is always there so you've got to fight it.

FAHS: How can radicals care for themselves then, given that they're dealing with extremes and the rejection that comes from doing something that deeply upsets the norm? Radicals are basically messing with the ideas that keep people safe, like what does it mean to be alive, or what is truth.

MOREA: It's difficult, but it's important to see things as a process rather than an end. If you're looking for a result, an end, it's easier to be cast aside. If you're not looking for an end, you're just staying in motion and it's much harder for you to be "captured" so to speak.

FAHS: I would imagine that the same will probably be said for you on some level, that once you put these things in motion that it doesn't end with your death or your disappearance, right?

MOREA: Absolutely it doesn't end. It's in a sense eternal. It just is. It's a wave, like sound waves and light waves. It's a wave and once it's out there, it's known 
but you need a receptor. Otherwise, it just remains a wave. It exists, but if it doesn't have a receptor, you cannot hear it or see it. So, I guess we look for receptors, ways to get things out in the world, and maybe that's why I came back after 40 years, to keep that wave from dissipating or being lost in the millions of other waves.

My whole thought pattern throughout the 60s was never limited to one field. I was never a political person solely. I always felt that politics, art, and culture were equally important. To me, cutting the fences at Woodstock was just as important as breaking down the doors at the Pentagon (which we also did). I didn't have a hierarchy of thought. That's what made me really different from most people because most people were really limited to each field. There were people who were totally artists, people who were involved in the political world, and there were people who were involved with the cultural and countercultural world. There was almost nobody who tried to join all of them. I think that's what helped save me because I could jump from one to the other or move between them. My identity wasn't so fixed. In a sense, I couldn't fail. I could fail politically, but artistically, culturally, I was okay. I always added the spiritual side as important. No political person ever saw spirituality-the spiritual act of creating-as important. I mean it in the non-religious sense. It's almost anti-religion.

FAHS: And you've said radicalism is creation, right? And the project of creation is in some ways so existential and huge that it has to have spiritual dimensions.

MOREA: Yes it does. It's totality. I used to use that word a lot: Totality. Or even in terms of connecting it to revolution, total revolution. In other words, I never limited the change necessary to one arena: political, artistic or cultural. They were all needed. I think the spiritual arena is even going to become more important because the Right Wing is fixated with religion, so the only way we're going to fight that is through a spiritual consciousness that is anti-religion. We replace religion with spirituality. Then you undermine their whole game. You show them up for what they are: small-minded bigots, who use religion just like they used Christ, killed him and used him. But Christ was just a rebel, too, a spiritual, anarchistic person. They wanted to make him into a God so they had a way to force you to follow them.

FAHS: That reminds me of the point you made about sexuality, this connection between religion and various kinds of pornography maybe, where they corrupt the fundamental creativity of sex and spirituality.

MOREA: It distorts it, and it uses it then to become a weapon, a weapon of control. So they control you - sexually, religiously-they control you. The whole game is to control. That's why I felt that we had to fight them on more fronts that just political because they wanted to control everything. It's so fundamental. 
They want you to believe that some book is the word of God. It's the word of man. God doesn't write. And I don't even like the word God. It was man who wrote it and they were writing it to keep you following his agenda, not your agenda.

FAHS: So resistance can happen in small ways all over the place, bubbling up, everything from people choosing different ways of dressing to different ways of eating.

MOREA: That's exactly it. At some point if one area is more controlled, it bubbles up in another area, so that way resistance continues its fermentation. It stays. It bubbles. It moves. At one point in time, it might have been a more political face, one point a more artistic face, but it keeps percolating, this idea of resistance. The radicals don't write history. Even the idea of history is already a problem, rather than his or herstory.

FAHS: So tell me this. Given that radicals don't write history, what do you imagine is the project of trying to have people learn from previous generations, pass down knowledge to later generations?

MOREA: Well, you have to trust people's instincts and creativity. You can't get the whole story, but you can get little glimmers of it, glimpses of it. Your creativity and your instinct has to help you sort through that. Read between the lines. I always think of looking for beacons. You don't even know the whole story of these people and maybe they weren't quite like you think they were, but there's some light that you glimpse and so you try to absorb it. Anarchists look for those lights while the political Marxist types want to read about it. Anarchists have to be able to sift through everything that's out there. Like cave paintings. When you realize these were human beings who were up against tremendous odds to survive and here they were creating. Or the aborigines in Australia who spent 20 hours a day to find food and shelter yet they created this tremendous amount of art. You've just got to find little things that completely resonate with you. You've got to read between the lines. Then, those writing the history can't control you because you're not going by the history. You're going by a bigger picture. You're making your own history.

\section{NOTES}

${ }^{1}$ Ben Morea and Ron Hahne, Black Mask \& Up Against the Wall Motherfucker: The Incomplete Works of Ron Hahne, Ben Morea, and the Black Mask Group (Oakland, CA: The PM Press, 2011), 160.

2 Henry Flynt, "Henry Flynt in New York, 20 East Broadway," http://www.youtube.com/watch?v=ONsoVep $5 \times 1$ s. 
${ }^{3}$ Morea and Hahne, Black Mask \& Up Against the Wall Motherfucker.

${ }^{4}$ Ibid., 152-153.

5 Osha Neumann, Up Against the Wall Motherfuckers: A Memoir of the 60s with Notes for the Next Time (New York: Seven Stories, 2008).

6 Morea and Hahne, Black Mask \& Up Against the Wall Motherfucker, 159.

7 The phrase comes from an Amiri Baraka poem where he writes, "The magic words are: Up against the wall, mother fucker, this is a stick up!” The phrase, "Up Against the Wall Motherfucker!" was also scrawled in the mathematics building during the occupation of Columbia University in 1968. These words were also included in student leader Mark Rudd's open letter to Columbia President Grayson Kirk: "I'll use the words of LeRoi Jones, whom I'm sure you don't like a whole lot: 'Up against the wall motherfucker, this is a stick up!' See Amiri Baraka, "Black People!", The LeRoi Jones/Amiri Baraka Reader (New York: Thunder's Mouth Press, 1999).

8 Abbie Hoffman, as quoted by Marty Jezer, Abbie Hoffman: American Rebel (New Brunswick, NJ: Rutgers University Press), 131-132.

9 "What is an Affinity Group?,"http://www.uproot.info/affinity.html.

10 Morea and Hahne, Black Mask \& Up Against the Wall Motherfucker, 163.

11 Ibid., 161.

12 Ibid., 157-158.

13 Ibid., 28.

14 SCUM Manifesto was first self-published in 1967. Of the published versions, I prefer the AK Press edition: Valerie Solanas, SCUM Manifesto (Oakland: AK Press, 1996).

15 My biography of Valerie Solanas, titled Valerie Solanas: Fragments and Forgetting, is forthcoming.

16 At the time of the interview, massive protests and uprisings were occurring throughout Egypt (March 2011).

17 The Chicago 1968 protests targeted the Democratic National Convention and included the Yippies (led by Abbie Hoffman and Jerry Rubin). 